\title{
Effects of a Foliar Neem Formulation on Colonization and Mortality of Whiteflies (Hemiptera: Aleyrodidae) on Collard Plants
}

\author{
Dana Krzyzaniak ${ }^{1,2}$, Alvin M. Simmons ${ }^{3 *}$, B. Merle Shepard ${ }^{4}$ \\ ${ }^{1}$ Academic Magnet High School, North Charleston, SC, USA \\ ${ }^{2}$ School of Chemical and Biomolecular Engineering, Georgia Institute of Technology, Atlanta, GA, USA \\ ${ }^{3}$ USDA-ARS, U.S. Vegetable Laboratory, Charleston, SC, USA \\ ${ }^{4}$ Coastal Research and Education Center, Clemson University, Charleston, SC, USA \\ Email: *alvin.simmons@ars.usda.gov
}

How to cite this paper: Krzyzaniak, D., Simmons, A.M. and Shepard, B.M. (2016) Effects of a Foliar Neem Formulation on Colonization and Mortality of Whiteflies (Hemiptera: Aleyrodidae) on Collard Plants. $A g$ ricultural Sciences, 7, 771-782. http://dx.doi.org/10.4236/as.2016.711071

Received: October 6, 2016

Accepted: November 4, 2016

Published: November 7, 2016

Copyright $\odot 2016$ by authors and Scientific Research Publishing Inc. This work is licensed under the Creative Commons Attribution International License (CC BY 4.0).

http://creativecommons.org/licenses/by/4.0/ (c) (i) Open Access

\begin{abstract}
A study was conducted to determine the effects of foliar sprays of a selected neem (Azadirachta indica A. Juss) product (GOS Neem 7-Way) on colonization and development by the Middle-East Asia Minor-1 (= B-biotype sweetpotato whitefly) Bemisia tabaci (Gennadius) on collard (Brassica oleracea variety acephala de Condolle) plants. GOS Neem 7-Way is marketed for use as an insecticide in organic and conventional crop production. Caged choice, caged no-choice, and Y-tube olfactometer assays were conducted on oviposition, survival and adult behavioral response to plant treatment with $1.25 \%$ azadiractin. In the caged choice experiment, colonization by the whiteflies was reduced and fewer eggs were deposited on neem-treated plants as compared with control plants (only treated with an adjuvant). Similarly, decreased numbers of adult whiteflies and reduced whitefly development were observed in no-choice assays for the neem-treatment, as compared with the untreated control. Both horizontal and vertical-orientated Y-tube olfactometer assays provided complementarily assessments that the neem had a repellency effect on the adult whiteflies. However, the repellency effect primarily dissipated within one day post treatment. Overall, the greatest benefit of the neem treatment appears to have been on whitefly mortality. The findings may be useful in providing a more ecologically sound way to manage populations of the B. tabaci whitefly in organic vegetable production.
\end{abstract}

\section{Keywords}

Bemisia tabaci, Vegetable, Biorational, Sustainability, Azadiractin 


\section{Introduction}

Whiteflies in the Bemisia complex are problematic on a wide range of crops on a global scale. The Middle-East Asia Minor-1 (MEAM1 = B-biotype sweetpotato whitefly) Bemisia tabaci (Gennadius) [1] (also reported as Bemisia argentifolii Bellows and Perring [2], is an important member of the Bemisia pest complex. This pest is very adaptable to its environment [3], and it has developed resistance to several insecticides [4] [5] [6] [7]. In addition to direct injury by feeding on over 1000 agricultural and wild hosts [8] [9] [10] this whitefly transmits over 300 species of plant viruses [11] which adds to its importance in agricultural production.

Growers commonly use synthetic insecticides to manage whiteflies. One appeal to this approach is that insecticides often suppress whitefly populations quickly. However, repeated use of conventional insecticides in agricultural systems has led to much concern about adverse effects on human health, the environment, insecticidal resistance in the whitefly target, adverse effects on non-target organisms, and other negative effects of insecticides [7] [12] [13]. Therefore, for sustainability, pest management options that incorporate a more compatible approach are desirable. Moreover, when an insecticide application is needed, cost, efficacy, and compatibility within the agricultural system are important considerations. Accordingly, biorational insecticides help fill certain critical needs by some growers, such as in organic agricultural production.

Azadiractin is an important plant-derived limonoid extract from the neem tree, Azadirachta indicate A. Juss, and it is used in insect pest management [14] [15] [16]. Azadiractin extracts are most commonly taken from neem seeds, the source for commercial use, but also are taken from leaves and fruits of this plant [17]. Azadiractin has activity against a wide range of insect pests as an insecticide and antifeeding deterrent [16] [18] [19] [20] [21]. However, with different formulations of azadiractin and different modes of applications, it is difficult to compare among studies [16]. Elevated storage temperature $\left(30^{\circ} \mathrm{C}\right)$, duration of storage and decreased concentrations can lower the efficacy of neem against a targeted pest [22]. Azadiractin is the most active compound in neem seed and is registered in the U.S. as a relatively non-toxic pesticide [23]. It is structurally similar to ecdysone which controls metamorphosis. If applied carefully, neem may be virtually less harmful compared to most commonly used pesticides [23].

Neem has been studied on several species of sucking insects. For example, in an aqueous state, it can affect the growth of Clavigralla scutellari (Westwood) (Hemiptera: Coreidae), a pest of pigeon pea plant (Cajanus cajan (L.) Millsp.) [24]. Dipping fourth instars of $C$. scutellari into neem solution and then held for continued development resulted in wing abnormalities that, in some cases, prevented the insect from flying. Aqueous neem also had severe effects on the cotton aphid (Aphis gossypii Glover) [25]. In the aphid study, the researchers found that neem extract reduced the fecundity of the aphids, and resulted in nymph mortality. Similar results were found during a study with neem on the southern green stink bug [Nezara viridula (Linnaeus)] [26]. In that study, researchers found that neem could affect molting by the nymphs and caused morphological defects in the adult stink bugs. These experiments suggest that neem 
may also have detrimental effects on the populations of whiteflies. The effects of neem on natural enemies vary [16] [27] [28] [29]. However, the quality among specific formulations of neem may not be consistent. For example, shelf life and storage conditions are factors which may affect efficacy. The objective of this study was to determine the effects of a selected formulation of neem (GOS Neem 7-Way) on the colonization and mortality of B. tabaci on collard host plants.

\section{Materials and Methods}

MEAM1 B. tabaci was obtained from a colony maintained on several vegetable crops [30] in a greenhouse. The genetic identity of this whitefly colony was recently reconfirmed [31] by polymerase chain reaction analyses of its DNA. For the assays in this study, adult whiteflies were taken directly from collard, Brassicaoleracae variety acephala de Condolle, plants. The whiteflies in the colony had not been exposed to chemicals before being used in the experiments. Likewise, collard plants for the assays were not exposed to any pesticides or other chemical except for liquid fertilizer. Both seedlings and mature plants were used for the experiments. Seedlings were held in a growth chamber at $28^{\circ} \mathrm{C}$, a photoperiod of $14: 10$ (light: dark) and $60 \pm 5 \%$ relative humidity. Plants used were similar in size, coloration, and number of leaves. Except where noted, seedlings were established in Jiffy starter pellets (Jiffy Products of America, Batavia, Illinois, USA) and were approximately $5 \mathrm{~cm}$ high. Older plants were potted and were about $20 \mathrm{~cm}$ tall.

During testing, plants were held in cages to keep them insect-free. Two types of cages were used. The cage used for testing seedlings was an 18 -cm-depth by $20-\mathrm{cm}$-diameter clear plastic cylinder that was covered with mesh on top, secured with rubber bands. Cages for larger plants were $0.61 \times 0.61 \times 0.61 \mathrm{~m}$ and constructed of 70 mesh chiffon screen with aluminum frames (Bio Quip Products, Rancho Dominguez, California, USA).

Neem treatment solution was applied to plants in a concentration of $37.0 \mathrm{~mL}$ of azadiractin per $3.79 \mathrm{~L}$ of water and an emulsifier of $7.39 \mathrm{~mL}$ per $3.79 \mathrm{~L}$. The neem, labeled as GOS Neem 7-Way, and emulsifier were obtained from Georgia Organic Solutions. The azadiractin was stored in a refrigerator at $2^{\circ} \mathrm{C}$ until used. The spray treatment was newly mixed each day and it was then applied to the plants using a plastic, handheld mist spray bottle.

A solution of water and emulsifier was sprayed on control plants and used as a comparison with the neem treatment. The control spray was comprised of only the emulsifier at the same concentration $(7.10 \mathrm{ml} / 3.79$ liters). The control solution was applied in the same manner as the neem solution. Adult whiteflies were collected and transported in $30 \mathrm{ml}$ plastic vials. Whiteflies were aspirated into the vials, capped with plastic tops and then released onto the collard plants. A compound microscope was used for examining the leaves for immature whiteflies while no magnification was used to observe the adult whiteflies.

Horizontal Y-tube assay. 
A horizontal Y-tube olfactometer was used for testing the relative attractiveness/repulsion of adult B. tabaci toward neem-treated plants. The olfactometer (as described [32]) was connected to a vacuum line that was calibrated to pulled a total flow of 4.2 L-min-1. Air was pulled across leaf surfaces of the samples in the separate compartments of the olfactometer. The olfactometer contained a neem-treated collard leaf in one arm of the Y-tube and a collard leaf that was only treated with water and the emulsifier in the other arm. Five adult whiteflies were released in the entrance of the olfactometer for each trial. After 25 minutes, the location of the whiteflies were observed and recorded based on which arm they were in or if they were still at the entrance. Four runs were done with the neem treatment in the right chamber of the olfactometer and four runs were done with the neem in the left chamber of the olfactometer. The experiment was repeated four times for a total of 160 insects.

\section{Vertical Y-tube Assay.}

An additional olfactometer assay was conducted using a vertical Y-tube olfactometer assay (as described [33]). This vertical orientation can complement the negative geotaxis and positive phototaxis behavior exhibited by many insects, including whiteflies, which tend not to exhibit movement readily in horizontally oriented olfactometers [32] [33] [34]. A 2-ml centrifuge vial was placed $6.3 \mathrm{~cm}$ below the top of an arm of the vertical olfactometer, and the vial was filled with deionized water. A vial of water was likewise setup in the other arm, and the stem of a detached leaf from a collard seedling was placed in the vial. The top of the tubes were covered with fine mesh screen. Thirty adult female whiteflies were allowed to escape from a $30 \mathrm{ml}$ vial that was placed on the floor of the olfactometer. A paired test was set up for two olfactometers, one with a control leaf and water check, and the other with a treated leaf and water check. Four pairs of olfactometers were set up for a given trial. The plants were set up on a laboratory bench with continuous light (1172 Lux at bench top) during the experiment. Temperature was $24 \pm 2^{\circ} \mathrm{C}$ during the exposure times. Data were taken on whitefly counts for a 90 minute expose to the plants at different time periods after the leaves were sprayed. Exposure times were $1-2.5,5-5.5,22.5$ - 24, and 46.5 - 48 hours post spray. After each exposure time, the numbers of live whiteflies of the leaf, in the check arm, in the base of the olfactometer and number of dead whiteflies and number of whitefly eggs on the upper and lower leaf surfaces within each olfactometer were recorded. The experiment was repeated five times for all exposure times except that three replicates were conducted for the 46.5 - 48 exposure.

\section{Caged Choice Tests.}

To conduct an additional assessment on the repellant effects of the neem solution on whiteflies, two similar-sized potted collard plants were placed into each of 20 large aluminum cages (as described above). Cages were held in an outdoors environment below a structure of $60 \%$ shade cloth (6426 Lux at ground level) which were completely opened on all sides. One plant was treated with neem solution, and the other plant was treated with the control solution, and both plants were placed in the same cage. After allowing the plants an hour to dry following the spray, a 30-ml vial containing 200 un- 
sexed adult whiteflies was placed of the floor inside of the cage and located between the two plants. The two plants were aligned east and west; 20 cages were set up and the cardinal location was alternated between each pair of plants for a given cage. The plants were left in the cage for 24 hours. After that time, each plant was removed and the numbers of adult whiteflies and eggs on each plant were counted and recorded. This procedure was repeated three times with new plants and insects.

\section{Egg Hatch.}

A no-choice experiment was set up to assess any neem effect on the incidence of egg hatch. Eight plastic cages (as aforementioned) containing five collard seedlings each were used, and 200 adult whiteflies of undetermined gender were added to each of the containers at $26 \pm 2{ }^{\circ} \mathrm{C}$. After 24 hours, the adult whiteflies were removed and the plants were treated with either the control or the neem solution. All plants within a cage were treated with the same treatment; five cages were treated with the control spray and five were treated with the neem spray. After 9 days, the leaves from each plant were removed and bagged. They were then taken to the laboratory and examined for the number of eggs and nymphs on each leaf. The experiment was repeated four times.

\section{Adult Emergence.}

A no-choice experiment was conducted to determine the effects of the neem formulation on the development of B. tabaci nymphs to the adult stage. Eight plastic cages (as aforementioned) containing five collard seedlings each were used. A total of 200 adult whiteflies were added to each container held at $26 \pm 2{ }^{\circ} \mathrm{C}$. After 24 hours, the adult whiteflies were removed. After 9 days were allowed for egg hatch, the plants were treated with either the control spray or the neem spray. All plants within a given cage were treated with the same treatment. Five cages of control plants and five cages with neem-treated plants were used. After 10 more days, the leaves from each plant were removed and bagged. They were then examined for the number of live nymphs, dead nymphs, and adults (based on empty exuviae) on each leaf. The experiment was repeated three times.

All data were analyzed with SAS 9.4 TS 1M2, Window version 6.2.9200 [35]. The independent variable was the neem applied to the collard. The dependent variables were numbers of eggs, nymphs and/or adults. The data were analyzed with ANOVA to assess any significant differences. Percentage data were arcsine-transformed before the analysis, but the results are presented on back-transformed data. Significant differences were determined at $\mathrm{P}<0.05$ unless otherwise noted.

\section{Results and Discussion}

\subsection{Horizontal Olfactometer Assay}

A significant difference $(\mathrm{F}=46.65, \mathrm{df}=62 ; \mathrm{P}<0.0001)$ in whitefly behavior, was observed with the horizontal olfactometer assay. Only $3.7 \pm 1.4 \%$ of the adult whiteflies resulted in the $\mathrm{Y}$-tube chamber with the neem treatment as compared with the control $(96.2 \pm 1.4 \%)$. This demonstrated a strong, but not absolute, repellency effect of neem on the whiteflies. 


\subsection{Vertical Olfactometer Assay}

Unlike the horizontal olfactometer, a vertical olfactometer is able to assay parameters beyond relative attractancy/repellency [33]. Significant detrimental impacts were observed on host acceptance and oviposition over time following the spray treatment of collard with neem in the vertical olfactometer assay (Figure 1(a), Figure $1(\mathrm{c})$ ). For the three exposure periods within $24 \mathrm{~h}$ post treatment, differences were observed in the percentage of released adults that were found on leaves of collard (Figure 1(a)). No significant difference between the treatment and the control was observed 2 days post treatment. Thus, the repellency had apparently dissipated by that time. Significantly elevated numbers of dead whiteflies were observed up to the 5 - 5.5 hours post treatment, but mortality was not significantly affected for the 1-day and 2-day post treatment exposures (Figure 1(b)). Although data were not taken on the location within the olfactometer where dead whiteflies were found, many of the dead whiteflies were observed on the top surface of the leaf and on the floor of the olfactometer. Significantly fewer eggs were deposited on the treated leaves during the three exposure periods during the first day post treatment, but not 2 days post treatment (Figure $1(\mathrm{c})$ ). For a given exposure time, it is not known if the time of the whitefly collection affected oviposition. Insects for a given exposure time was consistently collected either early morning, late morning, or mid-afternoon.

\subsection{Outdoors Caged Choice Test}

After 24 hours of the spray treatment, when given a choice between control and neemtreated plants, the adult whiteflies most often chose the control (untreated) plants. The average percentage of the whiteflies was significantly greater $(t=10.49 ; \mathrm{df}=118 ; \mathrm{P}<$ 0.0001) on the control plants than on the neem-treated plants (Table 1). There was an average of 0.78 adults per $\cdot \mathrm{cm}^{2}$ of leaf on control plants and 0.31 adults per $\cdot \mathrm{cm}^{2}$ of leaf on plants treated with neem. Moreover, there was a significant reduction $(t=7.31 ; \mathrm{df}=$ $178 ; \mathrm{P}<0.0001)$ in percentage of eggs on the neem-treated plants as compared with the control plants. Leaf area was statistically the same between the treated and control plants (Table 1). These data support that B. tabaci is less likely to infest plants and deposit eggs on plants treated with the neem formulation. Additionally, these data suggest that plants treated with the neem would be more likely to delay a whitefly population increase. These data complement the two aforementioned olfactometer experiments in further demonstrating the repulsion of the neem sprays to the adult whiteflies. Apparently, the decreased incidence in oviposition on the neem-treated plants may be because of the lower number of adults on those plants.

\subsection{No-Choice Egg Hatch Assay}

Neem-treated eggs had a significantly lower $(t=7.82 ; \mathrm{df}=130 ; \mathrm{P}<0.0001)$ hatch rate (61\%) as compared to the non-treated eggs which hatched at an average rate of $90 \%$ (Table 2). Reduction in egg hatch is important because this would result in an overall reduction in population level. Because most eggs are deposited on the lower surface of 
collard leaves, good spray coverage was more challenging on this surface than the top surface.

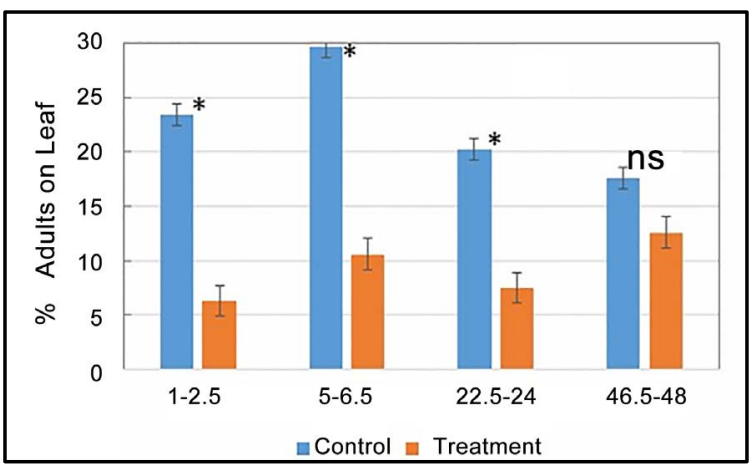

(a)

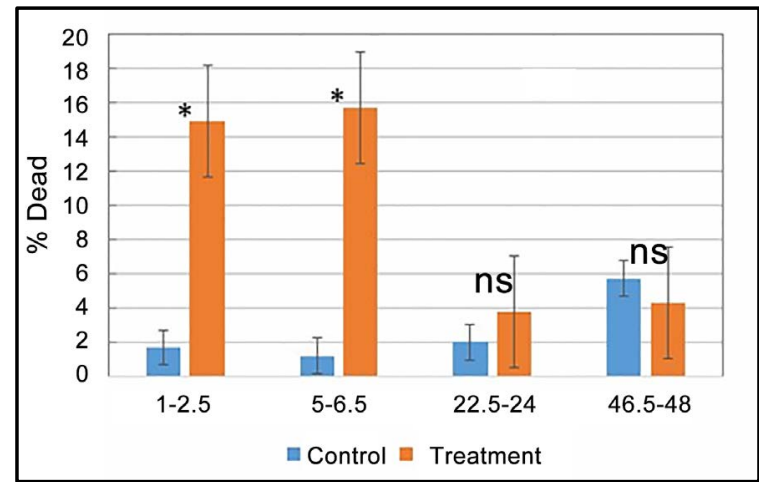

(b)

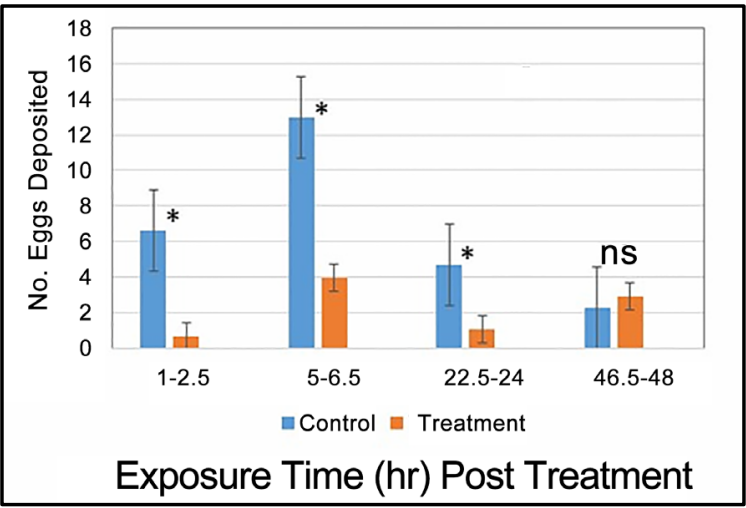

(c)

Figure 1. Mean percentage of 30 released adult B. tabaci that were: (a) alive on collard leaf; (b) percentage of the released that were dead; and (c) the number of eggs deposited, during 90 minutes at different exposure times after treatments of the leaf with neem or control spray. Asterisk above means for pairs within a given exposure time indicates significant difference at $\mathrm{P}<0.05$ while "ns" above means for pairs indicates no significant difference based on t-test. 


\subsection{Nymphal Survival}

Overall estimated adult emergence was low (25\%) for those on the control plants which was 8 -fold greater than the rate $(3 \%)$ for nymphs subjected to the neem treatment (Table 3). Considering the proportion of surviving nymphs and emerged adults provide a better comparison between treatments than counts of the whiteflies because the number of individuals in each cohort was not the same. Although some whiteflies in both treatments remained in the nymphal stage, high nymphal mortality $(71 \%)$ was observed for the neem treatment as compared with the check (8.8\%) (Table 3). Because the total number of eggs deposited was not determined, the assessment of percent adult emergence is probably an underestimation. In concert with results from the experiment on egg hatch, data in this experiment demonstrate the negative impact of the neem spray on survival of the immature whiteflies. Lower emergence levels would further decrease the population of whiteflies and slow future growth.

Table 1. Mean percentages of adult B. tabaci and eggs deposited on collard plants 24 hours after releasing 200 adult whiteflies in a cage containing a neem-treated plant and a control plant.

\begin{tabular}{cccc}
\hline Treatment & $\begin{array}{c}\text { \% of total number of adults on } \\
\text { plant pair } \pm \text { SEM (mean count) }\end{array}$ & $\begin{array}{c}\text { \% of total number of eggs on } \\
\text { plant pair } \pm \text { SEM (mean count) }\end{array}$ & Leaf area $\left(\mathrm{cm}^{2}\right)$ \\
\hline \multirow{2}{*}{ Control } & $\begin{array}{l}69.7 \pm 2.7 \mathrm{a} \\
(56.4 \pm 4.3)\end{array}$ & $72.6 \pm 4.4 \mathrm{a}(98.6 \pm 11.0)$ & $107.9 \pm 9.0 \mathrm{a}$ \\
& $\begin{array}{l}30.1 \pm 2.7 \mathrm{~b} \\
\text { Neem }\end{array}$ & $28.7 \pm 4.1 \mathrm{~b}(37.8 \pm 6.4)$ & $112.7 \pm 10.3 \mathrm{a}$ \\
\hline
\end{tabular}

Means within columns with different letters are significantly different $(\mathrm{P}<0.0001)$.

Table 2. Mean percent egg hatch by B. tabaci after treatment with neem-sprays on collard in non-choice laboratory cages.

\begin{tabular}{cc}
\hline Treatment & \% Egg hatch \pm SEM \\
\hline Control & $92.0 \pm 1.8 \mathrm{a}$ \\
Neem & $61.1 \pm 3.7 \mathrm{~b}$ \\
\hline
\end{tabular}

Means are significantly different $(\mathrm{P}<0.0001)$ according to ANOVA.

Table 3. Mean estimated incidence of adult emergence and incidence of live nymphs of $B$. tabci 10 days after collard plants containing first instar B. tabaci nymphs were treated with neemsprays and control sprays in non-choice laboratory cages.

\begin{tabular}{cccc}
\hline \multirow{3}{*}{ Treatment } & \multicolumn{3}{c}{ Average Incidence of Whiteflies } \\
\cline { 2 - 4 } & $\begin{array}{c}\text { \% of cohort as live nymphs } \\
\pm \text { SEM (mean count) }\end{array}$ & $\begin{array}{c}\text { \% of cohort as dead nymphs } \\
\pm \text { SEM (mean count) }\end{array}$ & $\begin{array}{c}\% \text { adult emergence } \pm \\
\text { SEM (mean count) }\end{array}$ \\
\hline \multirow{2}{*}{ Control } & $66.2 \pm 4.4$ & $8.8 \pm 4.4$ & $25.0 \pm 3.4$ \\
& $(26.3 \pm 4.6)$ & $(20.2 \pm 2.0)$ & $(14.4 \pm 4.6)$ \\
\hline \multirow{2}{*}{ Neem } & $25.9 \pm 5.5$ & $71.1 \pm 5.5$ & $3.0 \pm 1.4$ \\
& $(5.1 \pm 0.1)$ & $(6.2 \pm 4.9)$ & $(0.3 \pm 0.1)$ \\
\hline
\end{tabular}

Means within columns are significantly different $(\mathrm{P}<0.0001)$. 


\section{Conclusions}

The collective data from the different experiments in this study support that the evaluated neem formulation can have a significant detrimental effect on the population of B. tabci. Namely, the research suggests that spray application of the neem can repel the whiteflies as well as have a detrimental effect on egg hatch and nymphal development. This study only concerned a single application of the insecticide in confined environments. Multiple applications would be expected to provide greater efficacy against whiteflies. Further testing including assessment of efficacy of the neem against whiteflies in the field environment is needed to define frequency of application and how this biorational material could best fit in an integrated pest management program for whiteflies.

A disadvantage of using a foliar neem application for insect treatments is that it can have a negative effect on the populations of natural enemies [27] [29]. Various impacts of several biorational insecticides, including a neem formulation, have been demonstrated to have a negative impact on natural enemies (predators and parasitoids) of $B$. tabaci in vegetable crops [27] [29] [36]. However, delivery of neem through a soil or seed application may have less negative impact on predators and parasitoids as compared with a spray treatment [37] [38].

\section{Acknowledgements}

We thank: April Bisner and Bradford Peck for technical assistance, and thank Georgia Organic Solutions, Blakely, Georgia for supplying the azadiractin. This article reports the results of research only. Mention of a proprietary product does not constitute an endorsement or recommendation for its use by the USDA or Clemson University.

\section{References}

[1] Dinsdale, A., Cook, L., Riginos, C., Buckley, Y.M. and De Barro, P.J. (2010) Refined Global Analysis of Bemisia tabaci (Hemiptera: Sternorrhyncha: Aleyrodoidea: Aleyrodidae) Mitochondrial Cytochrome Oxidase 1 to Identify Species Level Genetic Boundaries. Annals of the Entomological Society of America, 103, 196-208. http://dx.doi.org/10.1603/AN09061

[2] Perring, T.M., Cooper, A.D., Rodriguez, R.J., Ferrar, C.A. and Bellows, T.S. (1993) Identification of a Whitefly Species by Genomic and Behavioral Studies. Science, 259, 74-77. http://dx.doi.org/10.1126/science.8418497

[3] Curnutte, L.B., Simmons, A.M. and Abd-Rabou, S. (2014) Climate Change and Bemisia tabaci (Hemiptera: Aleyrodidae): Impacts of Temperature and Carbon Dioxide on Life History. Annals of the Entomological Society of America, 107, 933-943. http://dx.doi.org/10.1603/AN13143

[4] Prabhaker, N., Coudreit, D.L. and Meyerdirk, D.E. (1985) Insecticide Resistance in the Sweetpotato Whitefly, Bemisia tabaci (Homoptera: Aleyrodidae). Journal of Economic Entomology, 78, 748-752. http://dx.doi.org/10.1093/jee/78.4.748

[5] Byrne, D.N., Bellows Jr., T.S. and Parrella, M.P. (1990) Whiteflies in Agricultural Systems, In: Gerling, D., Ed., Whiteflies: Their Bionomics, Pest Status, and Management, Intercept Ltd., Andover, Hants, 227-261.

[6] Horowitz, A.R., Konstedalov, S., Khasdan, V. and Ishaaya, I. (2005) Biotypes B and Q of Bemisia tabaci and Their Relevance to Neonicotinoid and Pyriproxyfen Resistance. Arc- 
hives of Insect Biochemistry and Physiology, 58, 215-225.

http://dx.doi.org/10.1002/arch.20044

[7] Gnankiné, O., Bassolé, I.H.N., Chandre, F., Glitho, I., Akogbeto, M., Dabire, R.K. and Martin, T. (2013) Insecticide Resistance in Bemisia tabaci Gennadius (Homoptera: Aleyrodidae) and Anopheles gambiae Giles (Diptera: Culicidae) Could Compromise the Sustainability of Malaria Vector Control Strategies in West Africa. Acta Tropica, 128, 7-17. http://dx.doi.org/10.1016/j.actatropica.2013.06.004

[8] Simmons, A.M., Harrison Jr., H.F. and Ling, K. (2008) Forty-Nine New Host Plant Species for Bemisia tabaci (Hemiptera: Aleyrodidae). Entomological Science (Japan), 11, 385-390. http://dx.doi.org/10.1111/j.1479-8298.2008.00288.x

[9] Abd-Rabou, S. and Simmons, A.M. (2010) Survey of Reproductive Host Plants of Bemisia tabaci (Hemiptera: Aleyrodidae) in Egypt, including New Host Records. Entomological News, 121, 456-465. http://dx.doi.org/10.3157/021.121.0507

[10] Abd-Rabou, S. and Simmons, A.M. (2014) Survey of Natural Enemies of Whiteflies (Hemiptera: Aleyrodidae) in Egypt with New Local and World Records. Entomological News, 124, 38-56. http://dx.doi.org/10.3157/021.124.0106

[11] Jones, D.R. (2003) Plant Viruses Transmitted by Whiteflies. European Journal of Plant Pathology, 109, 195-219. http://dx.doi.org/10.1023/A:1022846630513

[12] Cole, P.G., Cutler, A.R., Cobelt, A.J. and Horne, P.A. (2010) Acute and Long-Term Effects of Selective Insecticides on Micromus tasmaniae Walker (Neuroptera: Hemerobiidae), Coccinella transversalis F. (Coleoptera: Coccinellidae) and Nabis kinbergii Reuter (Hemiptera: Miridae). Australian Journal of Entomology, 49, 160-165.

http://dx.doi.org/10.1111/j.1440-6055.2009.00743.x

[13] Houndété, T.A., Kétoh, G.K., Hema, O.S.A., Brévault, T., Glitho, I.A. and Martin, T. (2010) Insecticide Resistance in Field Populations of Bemisia tabaci (Hemiptera Aleyrodidae) in West Africa. Pest Management Science, 66, 1181-1185. http://dx.doi.org/10.1002/ps.2008

[14] Schmutter, H. (1990) Properties and Potential of Natural Pesticides from the Neem Tree, Azadirachta indica. Annual Review of Entomology, 35, 271-297. http://dx.doi.org/10.1146/annurev.en.35.010190.001415

[15] Isman, M.B., Koul, O., Luczynski, A. and Kaminski, J. (1990) Insecticidal and Antifeedant Bioactivities of Neem Oils and Their Relationship to Azadirachtin Content. Journal of Agricultural and Food Chemistry, 38, 1406-1411. http://dx.doi.org/10.1021/jf00096a024

[16] Mordue (Luntz), A.J. and Blackwell, A. (1993) Azadirachtin: An Update. Journal of Insect Physiology, 39, 903-924. http://dx.doi.org/10.1016/0022-1910(93)90001-8

[17] Jacobson, M. (1990) Review of Neem Research in the United States. In: Locke, J.C. and Lawson, R.H., Eds., Proceedings of a Workshop on Neem's Potential in Pest Management Programs, USDA-ARS, Beltsville, 4-14.

[18] Baumgart, M. (1995) Effects of Neem (Azadirachta indica L.) Products on Feeding, Metamorphosis, Mortality, and Behavior of the Variegated Grasshopper, Zonocerus variegata (L.) (Orthoptera: Pyrgomorphidae). Journal of Orthoptera Research, 4, 19-28. http://dx.doi.org/10.2307/3503454

[19] Xie, Y.S., Fields, P.G. and Isman, M.B. (1995) Repellency and Toxicity of Azadirachtin and Neem Concentrates to Three Stored-Product Beetles. Journal of Economic Entomology, 88, 1024-1031. http://dx.doi.org/10.1093/jee/88.4.1024

[20] Isman, M.B. (1997) Neem and Related Natural Products. Methods in Biotechnology, 5, 139153.

[21] Banchio, E., Valladares, G., Defagò, M., Palacios, S. and Carpinella, C. (2003) Effects of $M e$ - 
lia azedarach (Meliacae) Fruit Extracts on the Leafminer Liriomyza huidobrensis (Diptera, Agromyzidae): Assesment in Laboratory and Field Experiments. Annals of Applied Biology, 143, 187-193. http://dx.doi.org/10.1111/j.1744-7348.2003.tb00285.x

[22] Boursier, C.M., Bosco, D., Coulibaly, A. and Negre, M. (2011) Are Traditional Neem Extract Preparations as Efficient as a Commercial Formulation of Azadirachtin A? Crop Protection, 30, 318-322. http://dx.doi.org/10.1016/j.cropro.2010.11.022

[23] Bond, C., Buhl, K. and Stone, D. (2012) Neem Oil General Fact Sheet. National Pesticide Information Center, Oregon State University Extension Services, Corvallis.

[24] Mitchell, P.L., Gupta, R., Singh, A.K. and Kumar, P. (2004) Behavioral and Developmental Effects of Neem Extracts on Clavigralla scutellaris (Hemiptera: Heteroptera: Coreidae) and Its Egg Parasitoid, Gryon fulviventre (Hymenoptera: Scelionidae). Journal of Economic Entomology, 97, 916-923. http://dx.doi.org/10.1603/0022-0493(2004)097[0916:BADEON]2.0.CO;2

[25] Santos, T.M., Costa, M.P., Torres, A.L. and Boica, A.L. (2004) Effect of Neem Extract on the Cotton Aphid. Pesquisa Agropecuária Brasileira, 39, 1071-1076. http://dx.doi.org/10.1590/S0100-204X2004001100003

[26] Abudulai, M. and Shepard, B.M. (2003) Effects of Neem on Nezara viridula (L.) (Hemiptera: Pentatomidae) and Its Major Parasitoid, Trissolcus basalis (Wollaston) (Hymenoptera: Scelionidae), in Cowpea. Journal of Entomological Science, 38, 398-408.

[27] Simmons, A.M. and Abd-Rabou, S. (2005) Incidence of Parasitism of Bemisia tabaci (Homoptera: Aleyrodidae) in Three Vegetable Crops after Application of Biorational Insecticides. Journal of Entomological Science, 40, 474-477.

[28] Rao, G.V.R., Visalakshmi, V., Suganthy, M. and Rao, V.R. (2007) Relative Toxicity of Neem to Natural Enemies Associated with the Chickpea Ecosystem: A Case Study. International Journal of Tropical Insect Science, 27, 229-235. http://dx.doi.org/10.1017/S1742758407877459

[29] Simmons, A.M. and Abd-Rabou, S. (2011) Populations of Predators and Parasitoids of Bemisia tabaci (Hemiptera: Aleyrodidae) after the Application of Eight Biorational Insecticides in Vegetable Crops. Pest Management Science, 67, 1023-1028. http://dx.doi.org/10.1002/ps.2155

[30] Simmons, A.M. (1994) Oviposition on Vegetables by Bemisia tabaci (Homoptera: Aleyrodidae): Temporal and Leaf Surface Factors. Environmental Entomology, 23, 381-389. http://dx.doi.org/10.1093/ee/23.2.381

[31] Chen, W., Hasegawa, D.K., Arumuganathan, K., Simmons, A.M., Wintermantel, W.M., Fei, Z. and Ling, K.S. (2015) Estimation of the Whitefly Bemisia tabaci Genome Size Based on K-Mer and Flow Cytometric Analyses. Insects, 6, 704-715. http://dx.doi.org/10.3390/insects6030704

[32] Coffey, J.L., Simmons, A.M., Shepard, B.M., Tadmor, Y. and Levi, A. (2015) Potential Sources of Whitefly (Hemiptera: Aleyrodidae) Resistance in Desert Watermelon (Citrullus colocynthis) Germplasm. HortScience, 50, 13-17.

[33] Coffey, J.L., Simmons, A.M., Shepard, B.M. and Levi, A. (2016) Vertical Y-Tube Assay for Evaluation of Arthropod Response to Plant Materials. Journal of Agricultural and Urban Entomology, 32, 7-12. http://dx.doi.org/10.3954/1523-5475-32.1.7

[34] Stelinski, L. and Tiwari, S. (2013) Vertical T-Maze Choice Assay for Arthropod Response to Odorants. Journal of Visualized Experiments, e50229. http://www.jove.com/video/50229 http://dx.doi.org/10.3791/50229

[35] SAS Institute (2014) SAS/STAT Version 9.4. SAS Institute, Cary. 
[36] Cóndor Golec, A.F. (2007) Effect of Neem (Azadirachta indica A. Juss) Insecticides on Parasitoids. Revista Peruana de Biología, 14, 69-74.

[37] Menke, S. and Gerhard, D. (2009) Detection of a Related Difference in Efficacy of Azadirachtin Treatments for the Control of Whiteflies on Gerbera jamesonii by Testing for Interactions in Generalized Linear Models. Pest Management Science, 66, 358-364.

[38] Karanja, J. and Poehling, H.-M. (2015) Efficacy and Dose Response of Soil-Applied Neem Formulations in Substrates with Different Amounts of Organic Matter, in the Control of Whiteflies, Aleyrodes proletella and Trialeurodes vaporariorum (Hemiptera: Aleyrodidae). Journal of Economic Entomology, 108, 1182-1190. http://dx.doi.org/10.1093/jee/tov047

Submit or recommend next manuscript to SCIRP and we will provide best service for you:

Accepting pre-submission inquiries through Email, Facebook, LinkedIn, Twitter, etc. A wide selection of journals (inclusive of 9 subjects, more than 200 journals)

Providing 24-hour high-quality service

User-friendly online submission system

Fair and swift peer-review system

Efficient typesetting and proofreading procedure

Display of the result of downloads and visits, as well as the number of cited articles

Maximum dissemination of your research work

Submit your manuscript at: http://papersubmission.scirp.org/

Or contact as@scirp.org 